\title{
Use and understanding of nutrition information on food labels in six European countries
}

\author{
Klaus G. Grunert • Laura Fernández-Celemín • Josephine M. Wills • \\ Stefan Storcksdieck genannt Bonsmann • Liliya Nureeva
}

Received: 6 August 2009 / Accepted: 24 November 2009/Published online: 6 January 2010

(C) The Author(s) 2009. This article is published with open access at Springerlink.com

\begin{abstract}
Aim The goal of the study was to investigate the use of nutrition information on food labels and understanding of guideline daily amount (GDA) front-of-pack nutrition labels in six European countries.

Subjects and methods In-store observations and in-store interviews were conducted in major retailers in the UK ( $n=$ 2019), Sweden $(n=1858)$, France $(n=2337)$, Germany $(n=$ 1963), Poland $(n=1800)$ and Hungary $(n=1804)$, supplemented by questionnaires filled out at home and returned (overall response rate $50.3 \%$ ). Use of labels was measured by combining in-store observations and in-store interviews on concrete purchases in six product categories. Understanding of GDA front-of-pack nutrition labels was measured by a variety of tasks dealing with conceptual understanding, substantial understanding and health inferences. Demographics, nutrition knowledge and interest in healthy eating were measured as potential determinants.

Results Across six product categories, $16.8 \%$ of shoppers were found to have looked for nutrition information on the label, with the nutrition grid (table or list), GDA labels and the ingredients list as the main sources consulted and calories, fat and sugar the information most often looked
\end{abstract}

K. G. Grunert $(\triangle) \cdot$ L. Nureeva

MAPP Centre for Research on Customer Relations

in the Food Centre, Aarhus University,

Haslegaardsvej 10 ,

8210 Aarhus V, Denmark

e-mail: klg@asb.dk

L. Fernández-Celemín · J. M. Wills •

S. Storcksdieck genannt Bonsmann

EUFIC-European Food Information Council,

Rue Guimard 19,

1040 Brussels, Belgium for. Understanding of GDA labels was high in the UK, Sweden and Germany, and more limited in the other countries. Regression analysis showed that, in addition to country-specific differences, use and understanding are also affected by differences in interest in healthy eating and in nutrition knowledge and by social grade.

Conclusion Understanding of nutrition information seems to be more widespread than use, suggesting that lack of use is a question of not only understanding, but also motivation. Considerable national differences exist in both understanding and use, some of which may be attributed to different histories of the role of nutrition in the public debate.

Keywords Nutrition information .

Consumer research on food labels $\cdot$ Signposting

\section{Background}

Recent reviews of published consumer research on use and understanding of nutrition information on food labels (Cowburn and Stockley 2005; Grunert and Wills 2007) have consistently pointed at two major shortcomings of the existing research. First, the majority of the studies carried out in Europe has been conducted in the UK. The UK has been the front-runner in Europe with regard to promoting nutrition labelling on food and especially front-of-pack (FOP) signposting, but for this very reason results obtained in the UK do not necessarily generalize to other parts of Europe. Furthermore, in the context of upcoming EU-wide legislation on the topic, insights that cover other parts of Europe are desirable. While studies in other parts of Europe have become more widespread recently (see studies cited in Grunert and Wills 2007), these have been mostly standalone studies, and the only multiple-country studies that 
allow some degree of comparison of results across countries have been a few studies conducted in a commercial or policy-making context, not published in the scientific press and with limited theoretical and methodological ambition. The only exception to this was a study conducted by Feunekes et al. (2008), in which a number of hypothetical label formats were tested in a laboratory experiment in four European countries. Secondly, as far as the use of nutrition information during shopping is concerned, almost all studies rely on self-reported retrospective use, which is believed to lead to considerable overreporting of use (Cowburn and Stockley 2005; Grunert and Wills 2007), and the few studies that are observational are qualitative, being based, for example, on accompanied shopping trips (e.g., Cadbury Schweppes 2005; Higginson et al. 2002; Malam et al. 2009).

The present study is a step towards overcoming both limitations. We collected data in six European countries using a common protocol. We employed a methodology combining in-store observation, an in-store interview and a take-home questionnaire, allowing us to come up with viable estimates of actual use of nutrition information while shopping, of consumers' degree of understanding of nutrition information on labels and how these are related to selected demographic and psychographic determinants. More specifically, the aims of the present study are:

1. To find out the proportion of shoppers looking for nutrition information when shopping for six selected product categories in six selected countries and to obtain insight into what information they looked for and where on the label they found it

2. To investigate, for the same shoppers in the same six countries, their degree of understanding of the most common FOP signposting scheme, namely the guideline daily amounts (GDA) label

3. To investigate how both use and understanding of nutrition information are related to demographic characteristics, nutrition knowledge and interest in healthy eating

The conceptual model guiding the study is shown in Fig. 1. It is an adaptation of the hierarchy of effects model proposed by Grunert and Wills (2007) for studying effects of nutrition labels on consumers, and it follows the tradition of streams of research in consumer decision-making and attitude formation and change (see e.g. Eagly and Chaiken 1993; McGuire 1985; Peter et al. 1999; Solomon et al. 2006). In order for nutrition labels to have any effect, consumers must be exposed to them and must perceive them. The effect will then be mediated by consumer understanding, which in turn will be affected by consumers' nutrition knowledge. Based on their understanding, consumers may then use the label information to make inferences about the healthiness of the product, which, together with other information (e.g. about the taste of the product), may affect the evaluation and eventually the purchase decision with regard to the product. Only the shaded parts of the model are dealt with in the present study.

\section{Design and methodology}

The study was carried out in six countries: the UK, Sweden, France, Germany, Poland and Hungary. The selection of countries was based on a number of criteria. The UK was selected as the country where FOP labelling has been most widely discussed and where the incidence of GDA information on products is highest (Fernandez-Celemin and Storcksdieck genannt Bonsmann 2009). France and Germany were selected because the incidence of FOP information likewise is high and for cultural diversity in terms of food and meals. In addition, France is one of the European countries besides the UK with a noticeable incidence of colour-coded labelling schemes. Sweden was selected as it is, in the EU, the country with the highest penetration of FOP health logos, in the form of the Swedish 'keyhole' logo. Poland and Hungary were included in order to have a representation of central Europe and of a low incidence of FOP information.

The study comprises three elements: an in-store observation, an in-store interview and an in-home questionnaire. Shoppers were observed at six selected aisles in the supermarket (breakfast cereals, yoghurts, ready meals, soft drinks, salty snacks and confectionery). When they had selected at least one product for purchase, they were approached for an interview about that particular purchase. At the end of the interview, they were asked if they would complete a further questionnaire at home and then return it.

Sampling and data collection

Observation and recruitment of participants occurred in major retailers (Tesco, Sainsbury's and Asda in the UK, Intermarché and Auchan in France, Lidl and Real in Germany, Tesco and Interspar in Hungary, Tesco and Real in Poland, ICA, Coop and Axfood in Sweden). In each country, data collection was additionally spread across three geographic locations. Six product categories were selected for the observational and in-store part: breakfast cereals, carbonated soft drinks, confectionery, ready meals, salty snacks and yoghurts. These categories were selected based on two criteria: they should cover both products where the retailer's own label is prominent (in those countries where private labels are prominent) and where branded goods manufacturers' labels are prominent, and they should cover products that differ in degree of overall perceived healthiness. 
Fig. 1 Conceptual framework

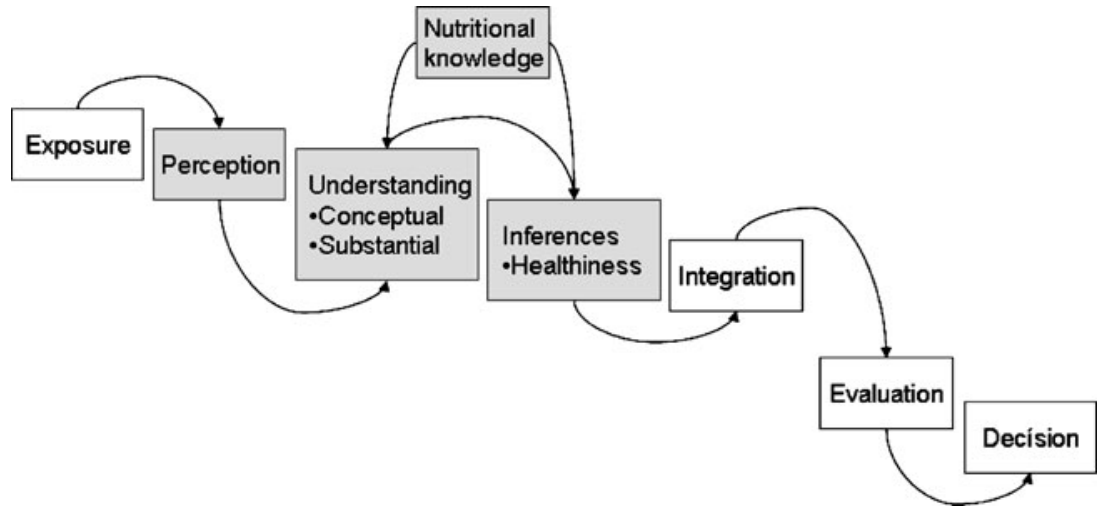

The interviews were carried out throughout a range of time segments on weekdays and at weekends. This resulted in a design with 3 retailers $\times 3$ locations $\times 6$ product categories $=54$ cells for countries where 3 retailers were included (UK, Sweden) and 2 retailers $\times 3$ locations $\times 6$ product categories $=$ 36 cells for the others (France, Germany, Poland, Hungary). The target cell size for data collection was 40 for countries where 3 retailers were used, with an overall target of 2,160 instore observations and interviews. The target cell size for data collection was 50 for countries where 3 retailers were used, with an overall target of 1,800 in-store observations and interviews. The final number of usable in-store observations and interviews was 2,019 for the UK, 1,858 for Sweden, 2,337 for France, 1,963 for Germany, 1,800 for Poland and 1,804 for Hungary. Return rates for the in-home questionnaire were $46 \%$ for the UK, $65 \%$ for Sweden, 36\% for France, $42 \%$ for Germany, 83\% for Poland and 39\% for Hungary. Demographic characteristics of the samples can be seen in Table 1. The data indicate a prevalence of women in the sample, which corresponds to the fact that women still have the main responsibility for food shopping in the majority of European households (Grunert et al. 2001). The spread with regard to social grade and age is very good. It should also be noted that the demographic profiles of the in-store sample and the subset of it that returned the in-home questionnaire are similar, indicating that there is not a problem with self-selection bias concerning the return of the in-home questionnaire.

In-store observation

The purpose of the in-store observation was to record whether people looked at the label of food products before buying them, where they looked and for how long. Observations took place at the aisles of the six product categories mentioned previously. Observation started whenever a shopper arrived at the aisle with the obvious intention of buying a product there. For each product handled in the aisle, it was recorded whether the shopper looked at the front of the product, looked elsewhere or did not look at the product in detail before putting it into the trolley. For each product handled, it was also recorded whether the product was placed in the trolley finally or replaced on the shelf/in the cooling counter. The time from arrival at the aisle and stopping for handling products until the product to be bought is put into the trolley (if several products are bought: until the last product bought is put into the trolley) was recorded in seconds using a stopwatch. Records from shoppers leaving the aisle without having put at least one product into the trolley were discarded. Observers were placed at the end of the aisle, with good overview of the aisle. Observed shoppers who had put at least one product into their trolley were approached and asked whether they were willing to participate in a short interview. Observational data for shoppers who declined to take part in the interview were discarded.

\section{In-store interview}

In the in-store interview, respondents were first asked for permission to record details of the first product they had selected in this aisle. They were then asked whether they had bought the product before and what the main reason was for selecting that particular product (open question). They were then asked whether they had looked for any nutrition information on the package of that product. When answering yes, respondents were asked to indicate what nutrition information they had looked for (open question). If respondents mentioned calories and nutrients, they were then asked whether the product just bought contained a lot, some or a little of it. Finally, respondents were asked to show on the package where they had found this information. Respondents were also asked how often they look for nutrition information in general when shopping for the product category in question.

The in-store interview also collected demographic information: age, gender and whether respondents have children under 16. Social grade was measured according to the UK National Statistics Socio-economic Classification (NS-SEC) system for the respondent household's chief earner. Categories 2 and 3 of that system were subsequently collapsed due to low numbers in category 3 (small 
Table 1 Sample characteristics

\begin{tabular}{|c|c|c|c|c|c|c|c|c|c|c|c|c|c|}
\hline & & \multicolumn{2}{|l|}{ UK } & \multicolumn{2}{|c|}{ Sweden } & \multicolumn{2}{|c|}{ France } & \multicolumn{2}{|c|}{ Germany } & \multicolumn{2}{|l|}{ Poland } & \multicolumn{2}{|c|}{ Hungary } \\
\hline & & $\begin{array}{l}\% \text { in- } \\
\text { store }\end{array}$ & $\begin{array}{l}\% \text { in- } \\
\text { home }\end{array}$ & $\begin{array}{l}\% \text { in- } \\
\text { store }\end{array}$ & $\begin{array}{l}\% \text { in- } \\
\text { home }\end{array}$ & $\begin{array}{l}\% \text { in- } \\
\text { store }\end{array}$ & $\begin{array}{l}\% \text { in- } \\
\text { home }\end{array}$ & $\begin{array}{l}\% \text { in- } \\
\text { store }\end{array}$ & $\begin{array}{l}\% \text { in- } \\
\text { home }\end{array}$ & $\begin{array}{l}\% \text { in- } \\
\text { store }\end{array}$ & $\begin{array}{l}\% \text { in- } \\
\text { home }\end{array}$ & $\begin{array}{l}\% \text { in- } \\
\text { store }\end{array}$ & $\begin{array}{l}\% \text { in- } \\
\text { home }\end{array}$ \\
\hline \multirow[t]{2}{*}{ Gender } & Male & 25.9 & 19.0 & 40.9 & 37.8 & 23.6 & 17.6 & 40.1 & 35.2 & 30.0 & 29.9 & 31.5 & 26.7 \\
\hline & Female & 74.1 & 81.0 & 59.1 & 62.2 & 76.4 & 82.4 & 59.9 & 64.8 & 70.0 & 70.1 & 68.5 & 73.3 \\
\hline \multirow[t]{4}{*}{ Social grade } & $\begin{array}{l}\text { Managerial and } \\
\text { professional }\end{array}$ & 22.7 & 22.9 & 49.6 & 51.0 & 17.7 & 18.5 & 38.0 & 41.6 & 35.1 & 34.0 & 25.3 & 23.6 \\
\hline & $\begin{array}{l}\text { Intermediate, small } \\
\text { employers }\end{array}$ & 36.5 & 36.7 & 24.7 & 24.5 & 42.8 & 45.4 & 26.5 & 29.2 & 25.3 & 24.0 & 22.1 & 21.8 \\
\hline & $\begin{array}{l}\text { Lower supervisory and } \\
\text { technical }\end{array}$ & 18.6 & 18.0 & 12.6 & 11.9 & 15.0 & 13.5 & 19.9 & 16.4 & 11.9 & 12.2 & 23.3 & 22.0 \\
\hline & Semi-routine and routine & 22.3 & 22.4 & 13.1 & 12.7 & 24.5 & 22.6 & 15.5 & 12.9 & 27.7 & 29.9 & 29.4 & 31.6 \\
\hline \multirow{2}{*}{$\begin{array}{l}\text { Parents with children } \\
<16 \text { years }\end{array}$} & Yes & 36.7 & 37.1 & 36.1 & 36.1 & 43.3 & 41.8 & 26.5 & 27.0 & 38.3 & 37.9 & 38.4 & 36.1 \\
\hline & No & 63.3 & 62.0 & 63.9 & 63.9 & 56.7 & 58.2 & 73.5 & 73.0 & 61.7 & 62.1 & 61.6 & 63.9 \\
\hline \multirow[t]{7}{*}{ Age } & -34 & 26.1 & 22.7 & 28.1 & 23.2 & 30.3 & 30.9 & 36.9 & 31.7 & 52.4 & 52.0 & 46.5 & 40.8 \\
\hline & $35-44$ & 24.1 & 25.0 & 21.7 & 22.6 & 24.4 & 26.2 & 19.1 & 20.1 & 18.9 & 18.8 & 24.4 & 24.8 \\
\hline & $45-54$ & 22.2 & 24.4 & 20.9 & 22.4 & 22.0 & 21.7 & 16.1 & 16.9 & 14.9 & 15.1 & 16.0 & 19.1 \\
\hline & $55-64$ & 14.9 & 15.4 & 16.2 & 17.6 & 12.8 & 12.0 & 12.7 & 14.8 & 10.4 & 10.2 & 9.8 & 11.2 \\
\hline & $65+$ & 12.7 & 12.4 & 13.1 & 14.2 & 10.5 & 9.2 & 15.2 & 16.4 & 3.4 & 3.9 & 3.4 & 4.1 \\
\hline & Total & 100.0 & 100.0 & 100.0 & 100.0 & 100.0 & 100.0 & 100.0 & 100.0 & 100.0 & 100.0 & 100.0 & 100.0 \\
\hline & Total, $n$ & 2,019 & 921 & 1,858 & 1,201 & 2,337 & 833 & 1,963 & 815 & 1,800 & 1,494 & 1,804 & 703 \\
\hline
\end{tabular}

employers and own account workers), resulting in a fourlevel classification as shown in Table 1.

Respondents received a monetary incentive for participating in the in-store interview and were offered an additional incentive if they completed a longer questionnaire at home and returned it.

\section{In-home questionnaire}

All respondents received a self-administered questionnaire, together with a return address envelope, to take home, fill out and return. This questionnaire consisted of three sections, containing measures on nutrition knowledge, understanding of FOP nutrition label formats and background information.

Understanding of FOP nutrition label formats was measured, in all six countries, with regard to GDA labels, as this is the only FOP label format that is currently in use in all six countries. We distinguished conceptual understanding and substantial understanding. In addition, we measured health inferences. Inferences go beyond understanding, but build on the understanding achieved (Kardes et al. 2004). We also measured subjective understanding on a scale from 1 (do not understand at all) to 10 (understand completely).

Conceptual understanding refers to whether respondents understand, at the general level, the meaning of the concept of GDAs. Conceptual understanding of GDAs was measured by multiple-choice questions on the definition of GDA, on the interpretation of a GDA reference value for fat of $70 \mathrm{~g}$ and on whether the reference for GDAs is per $100 \mathrm{~g}$, per serving or both/none of these. In addition, two other measures addressed specifically the question of whether people can distinguish and use correctly the percentage GDAs as opposed to the nutrient content in absolute terms on a GDA label. Respondents received two multiple-choice questions, one on the correct interpretation of a particular piece of information on the GDA label on a pack of crisps and the other based on GDA labels on three different products (a cereal product, a can of soft drink, a yoghurt), asking whether consuming a serving of each of these on a particular day would lead to the GDA for sugar on that day being surpassed, just reached or not reached. These tasks employed actual food labels as used in the respective countries.

Substantial understanding refers to whether respondents interpret the information on the label correctly. It was measured by presenting respondents with pictures of packaging of three actual ready meals (both front and back of pack) and asking them which of these were lowest in saturated fat per serving, lowest in calories per $100 \mathrm{~g}$, contained the highest GDA for sugar, provided more than half of the GDA of fat and contained the most salt (this is comparable to tasks used in earlier studies by the Food Standards Agency 2005; Which 2006). The different sets (each containing three products) were selected from the participating retailers' actual selection of ready meals, and therefore the sets of three products differ between countries. 
Information on the stimulus material is given in Table 9. While comparable, the tasks are thus not the same across countries. It was considered important that this task was realistic in the sense that it involves products actually on the market where respondents lived.

Health inferences refer to the question of whether respondents can use the label information to distinguish products in terms of their nutritional healthiness (previous studies measuring health inferences include Feunekes et al. 2008; Kelly et al. 2009; Malam et al. 2009; Which 2006). Four tasks measured health inferences. The first three tasks involved presentation of FOP nutrition labels only, with no additional information about the product. In the first task, respondents were presented with two labels for a fictitious product (a half pizza) and asked to indicate which one was healthier. One alternative dominated the other in that the labels were equal on sugar and salt and one was higher than the other on the remaining key nutrients and calories. In the second and third tasks, respondents were presented with three labels for a portion of a fictitious product (a pasta ready meal, except in Hungary, where pasta ready meals were not available and the task was hence framed also as referring to half a pizza) and asked which product was healthiest and which was least healthy. In both of these tasks, none of the alternatives was clearly dominant in terms of nutritional healthiness, they varied by either fat and calories, saturated fat or salt content, thus representing real life. For these three tasks, the label format used for all subsamples except the French one was the GDA format developed by the Confederation of the Food and Drink Industries of the EU (CIAA) and used by major brand manufacturers. In France, the format used was the one adopted by the French retailer Auchan, which is a bit different in terms of layout and omits information on saturated fat. This format was used for the French respondents as it was believed to be the most well-known version of the GDA label in France. Nutrient values in grams, calories and \% GDA values were identical in all subsamples except for the three-label task in Hungary, where the values were adapted to the different framing of the task (half pizza instead of pasta ready meal) while preserving the same pattern. The stimulus material used for these tasks can be seen in Figs. 2 and 3a, b.

Finally, for the fourth task, respondents were asked to rank the three actual ready meals used in the substantial understanding task in terms of healthiness. Here, ranking the products in terms of healthiness was clear from objective nutritional considerations. The ranking task was supplemented by an open question asking the respondent to list up to three informational items on which they had based their ranking.

In addition to the demographic information already collected in the store, respondents were asked to indicate their weight and height, allowing the computation of the body mass index (BMI). Interest in healthy eating was measured using seven items developed by Roininen et al. (1999). These items were converted into a sum score for further analysis, with lower scores indicating more interest in healthy eating. Cronbach's $\alpha$ varied between .75 and .84 , indicating good internal consistency.

Nutrition knowledge was measured by an instrument containing three parts. The first part measured respondents' knowledge on dietary recommendations and consisted of 12 items measuring perceptions on whether health experts recommend that one should have more, about the same, less or try to avoid a series of nutrients, calories or ingredients, and 7 items measuring perceptions on whether health experts recommend that one should have a lot, some, a little or try to avoid different food groups. The former was adapted from the similar list in Parmenter and Wardle (1999) and the latter from an earlier Food Standards Agency study (Food Standards Agency 2007). This resulted in a total of 19 items for the first part. The second part, also adapted from Parmenter and Wardle (1999), measured respondents' knowledge on sources of nutrients and asked them, for 18 different products, to indicate whether they were high or low in fat, saturated fat, salt and sugar, resulting in a total of 72 items for the second part. The third part measured respondents' knowledge on the calorie content of food and drink products, to give an indication of their knowledge of the approximate energy (calorie) content of specific food and drinks. For indicated serving sizes of eight different products, respondents were asked to choose the amount of calories in that serving from a scale consisting of seven calorie ranges. For analysis, the answer for each item was coded as right or wrong, and an overall index of nutrition knowledge was constructed according to the following formula:

\section{Nutrindex \\ $=($ number of correct answers dietary recommendations $/ 19)$ + (number of correct answers sources of nutrients/72) + (number of correct answers calorie content of food and drink products $/ 8$ )}

Details on the results concerning nutrition knowledge are reported elsewhere, and in the present paper only the nutrition knowledge index will be used as a potential determinant of nutrition information use in the shop and of understanding of FOP nutrition information. The questionnaire also contained a few other measures not reported in this paper.

\section{Results}

Results will first be presented for use of nutrition information in the shop, then for understanding of FOP 
Fig. 2 Evaluation of healthiness based on two labels ( $\%$ of respondents returning the home questionnaire in each country)

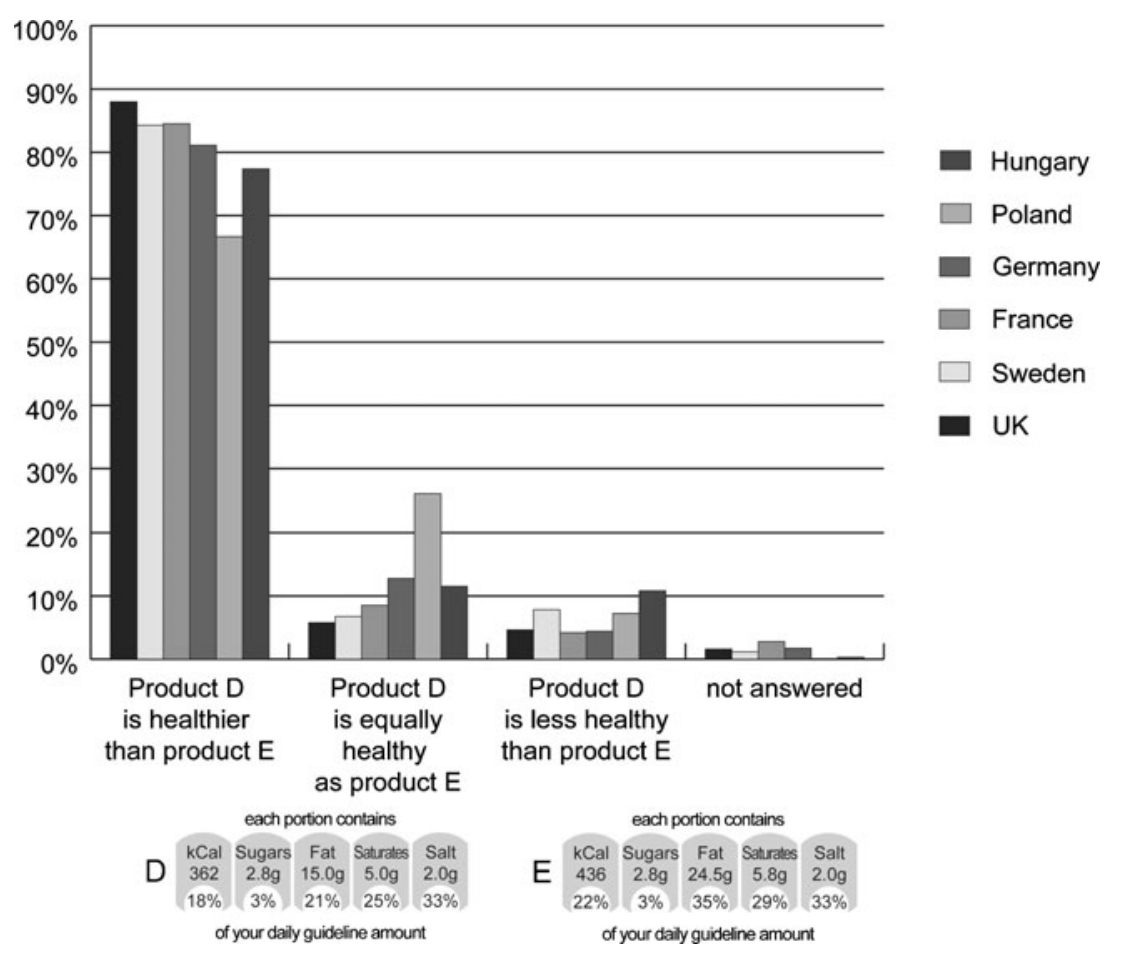

nutrition information. For both sections, we will first present descriptive statistics and then analyse the relationships between these variables and demographic and psychographic characteristics.

Use of nutrition information in the store

The observational data showed that respondents bought on average 1.4 (1.2 in Hungary, Poland and Germany, 1.4 in Sweden and France, 1.8 in the UK) products in the aisle where they were observed, and spent, on average, $35 \mathrm{~s}$ per product bought (28 in the UK and Germany, 30 in France, 31 in Sweden, 47 in Poland and Hungary). The average time was highest when buying ready meals (43 s) and lowest for salty snacks $(31 \mathrm{~s})$. The figures show that purchases were not completely habitual and people took time to look at products. This is supported by the finding that $62.6 \%$ of respondents were observed to have looked at the front of the package and $7.7 \%$ were observed to have looked at it elsewhere (these figures refer to the first product bought). Across all product categories and countries, the most common main reason given for choosing this particular product was taste $(52 \%)$ followed by 'this is what my family wants' $(13.4 \%)$, price/special offer $(10.7 \%)$ and health/nutrition ( $8 \%)$.

The percentages of respondents answering yes when asked whether they had looked for nutrition information on the first product they had bought in the aisle are shown in Table 2. Across countries and product categories, 16.8\% said they had looked for nutrition information. There is considerable variation, though, over both product categories and countries: Shoppers were most likely to look for nutrition information when buying yoghurt and breakfast cereals, and they were most likely to do so in the UK (27\%) and least likely in France (8.8\%).

In order to validate the 'yes' answers to this question, all respondents answering 'yes' were asked to name at least one nutrient they looked for (including calories) and to show on the package where they found the information. All respondents who had answered 'yes' could name at least calories or one nutrient they had looked for and could show on the package where they had found that information. Also, of those claiming to have looked for nutrition information on the package, $74.7 \%$ had been observed to have looked at the product (front or elsewhere). Of those who were observed not having looked at the product in detail, but who still claimed to have looked for nutrition information, $90.7 \%$ had bought the same product before, and may have recalled the information from a previous purchase or just very briefly have confirmed the information they already knew.

Table 3 shows which information the shoppers looked for. It is clear that calories, fat and sugar are the three most frequently looked for pieces of information, though there is some country-specific deviation: calories are clearly less frequently looked for in Sweden, and fat is clearly less looked for in Hungary. Beyond the most frequently sought, country differences become more pronounced. Sodium and saturated fat are the next most frequently sought in the UK, showing that the UK pattern of information search follows the 
Fig. 3 a Evaluation of healthiness based on three labels ( $\%$ of respondents returning the home questionnaire in each country). In the French subsample, stimulus material corresponded to the Repères Nutritionnels format and did not contain information on saturates. In Hungary, stimulus values were I-315 (16\%) calories/0.8 g (1\%) sugar/10.1 g (14\%) fat $/ 5.6 \mathrm{~g}(28 \%)$ saturates/1.5 g (25\%) salt; J-482 (24\%) calories/0.8 g (1\%) sugar/29 g (41\%) fat/1.6 g (8\%) saturates/ $3 \mathrm{~g}(50 \%)$ salt; K-315 (16\%) calories/0.8 g (1\%) sugar/10.1 g (14\%) fat/9 g (45\%) saturates/ $1.5 \mathrm{~g}(25 \%)$ salt. b Evaluation of healthiness based on three labels (\% of respondents returning the home questionnaire in each country). In the French subsample, stimulus material corresponded to the Reperres Nutritionnels format and did not contain information on saturates. In Hungary, stimulus values were F-399 (20\%) calories/0.8 g (1\%) sugar/25 g (36\%) fat/2.3 g $(12 \%)$ saturates/1 g (17\%) salt; G-315 (16\%) calories/0.8 g (1\%) sugar/9.5 g (14\%) fat/7.6 g (38\%) saturates/1 g (17\%) salt; H-285 (14\%) calories/0.8 g (1\%) sugar/9.5 g (14\%) fat/2.3 g $(12 \%)$ saturates/2.2 g (37\%) salt a

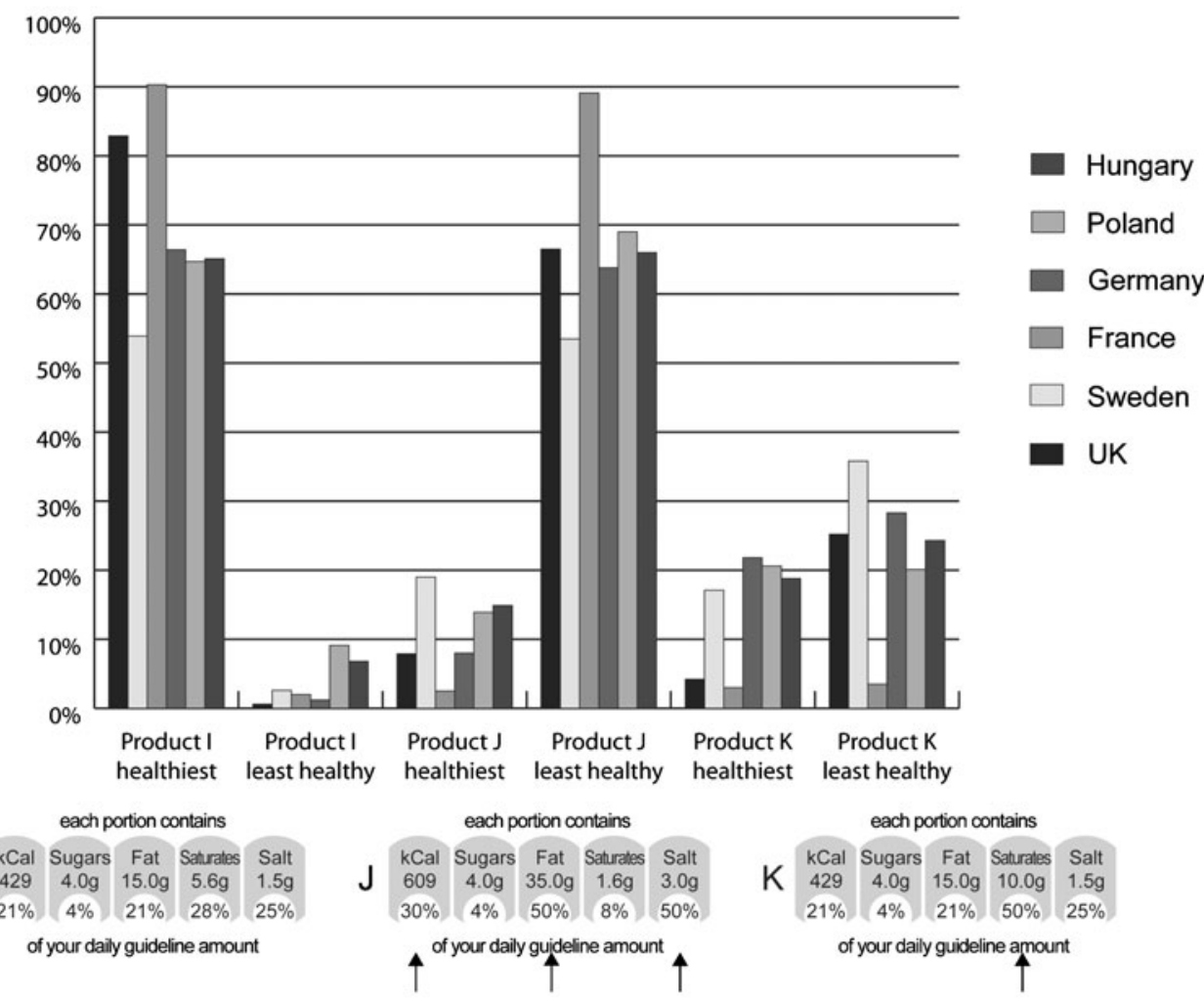

b

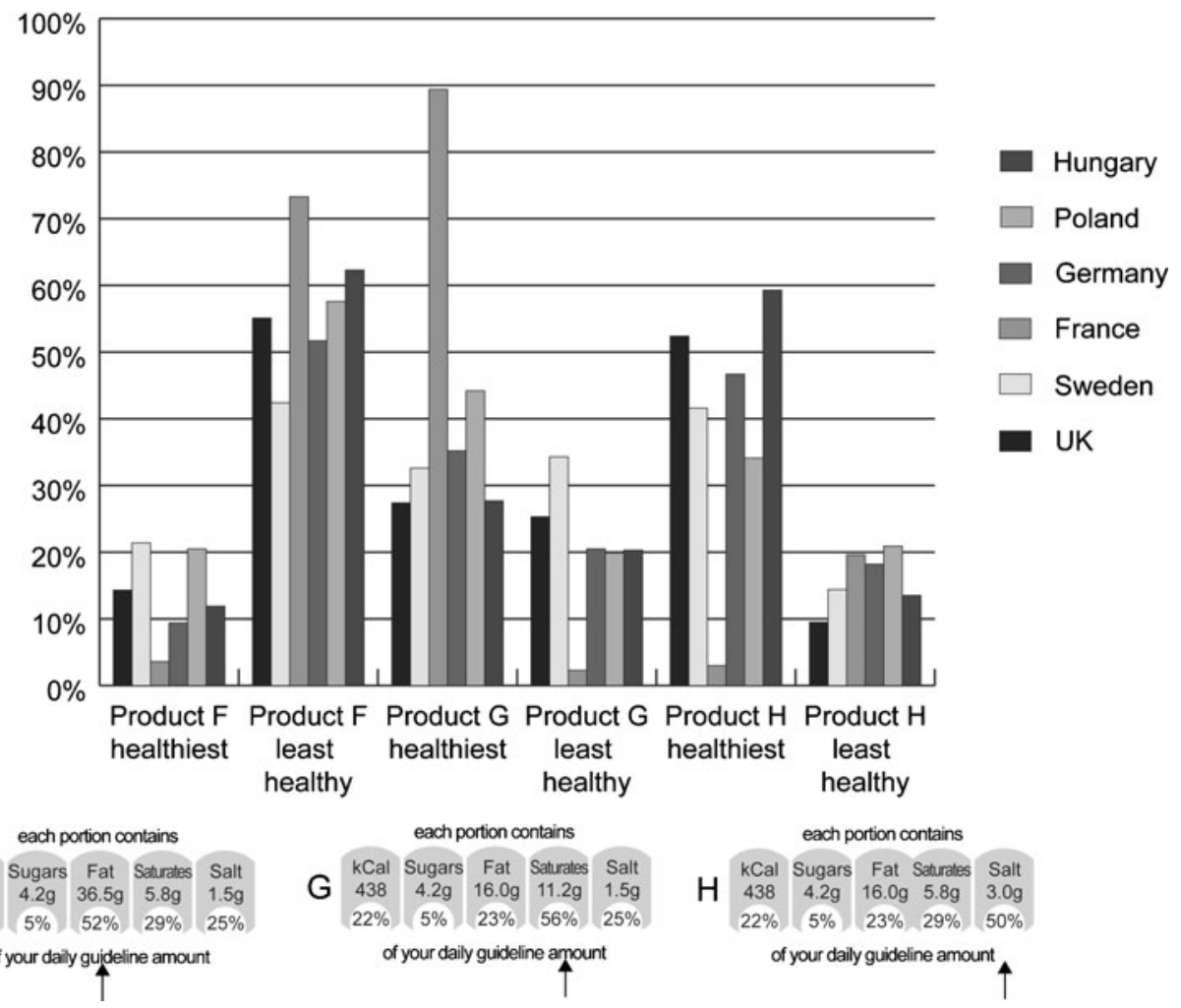


Table 2 Share of respondents who looked for nutrition information in the aisle (\% of respondents who were observed and bought at least one item in the respective aisle)

\begin{tabular}{lrrrrrrr}
\hline & UK & Sweden & France & Germany & Poland & Hungary & Total \\
\hline Ready meals & 28.3 & 11.3 & 15.7 & 16.1 & 10.4 & 15.8 & 16.7 \\
Carbonated soft drinks & 23.3 & 4.9 & 7.0 & 19.1 & 10.8 & 15.4 & 12.9 \\
Yoghurt & 37.8 & 21.1 & 12.1 & 30.6 & 15.8 & 25.3 & 23.5 \\
Breakfast cereal & 34.4 & 24.1 & 13.0 & 25.5 & 24.2 & 27.4 & 24.5 \\
Confectionary & 15.8 & 8.1 & 2.9 & 15.1 & 12.1 & 13.3 & 11.0 \\
Salty snacks & 22.0 & 10.2 & 3.6 & 11.6 & 9.2 & 15.9 & 11.8 \\
All product categories & 27.0 & 13.5 & 8.8 & 19.7 & 13.8 & 18.8 & 16.8 \\
\hline
\end{tabular}

five key nutrients concept applied in both GDA and traffic light labelling, and possibly reflecting recent UK government campaigns about salt and saturated fat. Vitamins are often looked for in Poland, and organic production is often looked for in Germany (categorized as 'other' in Table 3).

Table 4 tabulates where shoppers found the information they were looking for, for the five key nutrients/calories. This is based on the shoppers showing where they found the information on the package. It can be seen that three sources of information are the most frequently looked for: the nutrition grid (table or list), usually on the back of the package, the GDA label, usually on the front of the package, and the ingredients list. The result on use of GDA labels must be seen in the light of the selection of product categories, which included some categories (breakfast cereal, soft drinks, yoghurt) where GDA labels are widely available on products of international brand manufacturers. Colour-coded systems are mentioned only in France and the $\mathrm{UK}$, as the only countries having such labelling.

Determinants of looking for nutrition information were investigated by logistic regression, with the binary variable 'has looked for nutrition information' as the dependent variable. Three groups of determinants were investigated: demographic, psychographic and situational. Demographic variables included age, gender, having children under
16 years of age (yes/no), country and BMI. Psychographic determinants included interest in healthy eating and nutrition knowledge. Situational determinants included the product category bought and the main reason given by the respondent for choosing the product (health/nutrition, taste, price/on offer, other). These three sets of variables were entered into three blocks, with demographic variables first, then psychographic and then situational. Note that this analysis draws on variables from the in-home questionnaire, and therefore only respondents returning the in-home questionnaire are included.

Results of the logistic regression are given in Table 5. The percentage of explained variance for the most complete model is $15 \%\left(\right.$ Nagelkerke $\left.R^{2}\right)$. A number of significant and interesting effects emerge. First of all, we see again the country effect (reported above), with UK shoppers having the highest and French shoppers the lowest probability of looking for nutrition information. There is also a gender effect, with women having a higher probability, and a social grade effect, with lower social grades having a lower probability. Age, having children under 16 and BMI have no significant effects. In the second step, both interest in healthy eating and nutrition knowledge have effects in the expected direction. In the third step, we see that the probability of looking for nutrition information is lower

Table 3 Nutrition information looked for by country ( $\%$ of respondents that said they had looked for nutrition information in the aisle per country)

\begin{tabular}{|c|c|c|c|c|c|c|c|}
\hline & UK & Sweden & France & Germany & Poland & Hungary & Total \\
\hline Calories & 32.7 & 17.5 & 46.6 & 49.0 & 65.7 & 33.4 & 39.6 \\
\hline Fat & 49.3 & 45.0 & 33.3 & 49.2 & 36.7 & 5.1 & 38.0 \\
\hline Sugar & 34.9 & 45.0 & 37.3 & 42.7 & 31.4 & 13.1 & 33.8 \\
\hline Food additives/colours/preservatives/E-numbers & 10.1 & 7.2 & 11.8 & 9.3 & 31.8 & 13.4 & 13.0 \\
\hline Carbohydrates & 5.0 & 10.0 & 8.8 & 20.7 & 18.0 & 14.0 & 12.3 \\
\hline Sodium/salt & 20.0 & 3.2 & 7.4 & 4.7 & 9.8 & 0.9 & 9.0 \\
\hline Vitamins & 2.6 & 3.2 & 3.4 & 7.5 & 26.5 & 5.4 & 7.2 \\
\hline Protein & 2.6 & 6.8 & 6.9 & 8.5 & 6.1 & 6.0 & 5.8 \\
\hline Saturated fat & 11.2 & 6.0 & 4.4 & 2.6 & 5.3 & 0.9 & 5.6 \\
\hline Fibre & 4.0 & 8.8 & 4.9 & 3.9 & 16.3 & 0.3 & 5.6 \\
\hline Other & 21.3 & 26.3 & 11.3 & 42.2 & 45.7 & 6.0 & 25.4 \\
\hline
\end{tabular}


Table 4 Sources of nutrient information by country for calories, sugar, fat, saturated fat and sodium $/$ salt $(\%$ of respondents who looked for any of these five in the respective country)

\begin{tabular}{lrrrrrrr}
\hline & UK & Sweden & France & Germany & Poland & Hungary & Total \\
\hline GDA & 40.5 & 10.2 & 39.1 & 38.6 & 15.9 & 11.7 & 29.2 \\
Traffic lights & 8.4 & 0 & 3.0 & 0 & 0 & 0 & 2.8 \\
Health logo & 3.7 & 1.0 & 4.1 & 4.0 & 8.2 & 12.3 & 5.1 \\
Specific claim & 7.9 & 13.7 & 4.7 & 1.6 & 4.8 & 0.6 & 5.7 \\
Nutrition grid & 28.4 & 43.9 & 27.2 & 38.6 & 53.8 & 50.8 & 38.5 \\
Ingredient list & 8.6 & 15.1 & 5.3 & 8.4 & 16.3 & 19.0 & 11.3 \\
Colour-coded GDA & 2.2 & 0 & 0 & 0 & 0 & 0 & 0.7 \\
Other & 3.5 & 1.0 & 0.6 & 6.9 & 0 & 0 & 2.7 \\
\hline
\end{tabular}

for soft drinks, confectionary and salty snacks, as compared to ready meals, yoghurts and breakfast cereal. We also see, not surprisingly, that the likelihood of looking for nutrition information decreases when health/nutrition is not the primary reason for choice.

It can be seen that the effects of country, gender and social grade become smaller in the second step when the two psychographic variables are introduced, suggesting that the effects of country, gender and social grade may be partially mediated by interest in healthy eating and nutrition knowledge. To investigate this further, two additional regressions were run, where the set of demographic variables was used as predictors for interest in healthy eating and nutrition knowledge. The results for nutrition knowledge, in Table 6, show that nutrition knowledge is influenced by the country variable (highest in the UK,

Table 5 Determinants of use of nutrition information in store (logistic regression)

\begin{tabular}{|c|c|c|c|c|c|c|c|c|c|c|c|c|}
\hline \multirow[b]{3}{*}{ Age } & \multirow{2}{*}{\multicolumn{4}{|c|}{$\begin{array}{l}\text { B } \quad \text { SE } \quad \text { Sig. } \quad \text { Exp (B) } \\
\text { Step 1, Nagelkerke } R^{2}=.05\end{array}$}} & \multirow{2}{*}{$\begin{array}{l}\text { B } \\
\text { Step 2, }\end{array}$} & \multirow{2}{*}{$\begin{array}{l}\text { SE } \\
\text { Nagelk }\end{array}$} & \multirow{2}{*}{\multicolumn{2}{|c|}{$\begin{array}{l}\text { Sig. } \quad \operatorname{Exp}(\mathrm{B}) \\
\text { erke } R^{2}=.09\end{array}$}} & \multirow{2}{*}{$\begin{array}{l}\text { B } \\
\text { Step 3, }\end{array}$} & \multirow{2}{*}{$\begin{array}{l}\text { SE } \\
\text { Nagell }\end{array}$} & \multicolumn{2}{|c|}{ Sig. $\operatorname{Exp}(B)$} \\
\hline & & & & & & & & & & & & \\
\hline & .005 & .003 & .098 & 1.005 & .001 & .003 & .710 & 1.001 & .000 & .003 & .806 & .999 \\
\hline Gender (base: female) & -.346 & .094 & .000 & .708 & -.228 & .096 & .017 & .796 & -.168 & .098 & .086 & .845 \\
\hline Child (base: no) & -.088 & .087 & .314 & .916 & -.059 & .088 & .501 & .942 & -.046 & .091 & .616 & .955 \\
\hline BMI & .002 & .009 & .823 & 1.002 & .008 & .009 & .383 & 1.008 & .011 & .009 & .261 & 1.011 \\
\hline Country (base: UK) & & & .000 & & & & .000 & & & & .000 & \\
\hline Sweden & -.805 & .127 & .000 & .447 & -.567 & .132 & .000 & .567 & -.508 & .137 & .000 & .602 \\
\hline France & -1.251 & .162 & .000 & .286 & -1.156 & .165 & .000 & .315 & -.998 & .170 & .000 & .368 \\
\hline Germany & -.319 & .131 & .015 & .727 & -.080 & .135 & .553 & .923 & .077 & .142 & .586 & 1.080 \\
\hline Poland & -.721 & .130 & .000 & .486 & -.468 & .136 & .001 & .626 & -.273 & .144 & .058 & .761 \\
\hline Hungary & -.262 & .144 & .068 & .770 & -.095 & .147 & .518 & .909 & .096 & .153 & .530 & 1.101 \\
\hline Social grade (base: managerial, professional) & & & .000 & & & & .002 & & & & .004 & \\
\hline Intermediate, small employers & -.281 & .100 & .005 & .755 & -.256 & .102 & .012 & .774 & -.282 & .105 & .007 & .755 \\
\hline Lower supervisory and technical & -.255 & .126 & .043 & .775 & -.161 & .128 & .208 & .851 & -.133 & .131 & .310 & .875 \\
\hline Semi-routine and routine & -.558 & .120 & .000 & .573 & -.444 & .122 & .000 & .641 & -.412 & .125 & .001 & .662 \\
\hline Interest in healthy eating & & & & & -.553 & .063 & .000 & .575 & -.487 & .065 & .000 & .614 \\
\hline Nutrition knowledge & & & & & .351 & .119 & .003 & 1.421 & .345 & .122 & .005 & 1.411 \\
\hline Product (base: ready meals) & & & & & & & & & & & .000 & \\
\hline Soft drinks & & & & & & & & & -.387 & .154 & .012 & .679 \\
\hline Yoghurts & & & & & & & & & .200 & .138 & .149 & 1.221 \\
\hline Breakfast cereals & & & & & & & & & .239 & .140 & .088 & 1.269 \\
\hline Confectionary & & & & & & & & & -.543 & .162 & .001 & .581 \\
\hline Salty snacks & & & & & & & & & -.332 & .155 & .032 & .717 \\
\hline Main reason (base: health-nutrition) & & & & & & & & & & & .000 & \\
\hline Taste & & & & & & & & & -1.231 & .137 & .000 & .292 \\
\hline Price & & & & & & & & & -1.161 & .181 & .000 & .313 \\
\hline Other & & & & & & & & & -1.126 & .138 & .000 & .324 \\
\hline Constant & -.346 & -1.941 & .241 & .144 & -1.136 & .357 & .001 & .321 & -1.103 & .368 & .003 & .332 \\
\hline
\end{tabular}


lowest in France and Poland), age (lower for higher age) and social grade (lower for lower social grades). The results for interest in healthy eating show again effects of country (UK and France highest), social grade (lower for lower social grades) and age (higher for higher age), and in addition also effects of gender (interest in healthy eating higher for women) and BMI (interest in healthy eating lower for higher BMIs). The Sobel test statistic for indirect effects in mediation analysis (Baron and Kenny 1986) shows that all of the significant effects of the demographic variables on interest in healthy eating and on nutrition knowledge in Table 6 also entail significant indirect effects

Table 6 Determinants of nutrition knowledge and interest in healthy eating (regression)

\begin{tabular}{|c|c|c|c|}
\hline & $\mathrm{B}$ & $\mathrm{SE}$ & Sig. \\
\hline \multicolumn{4}{|l|}{ Dependent: Nutrition knowledge } \\
\hline Intercept & 1.629 & 0.036 & 0.000 \\
\hline \multicolumn{4}{|l|}{ Country (base: UK) } \\
\hline Sweden & -0.149 & 0.018 & 0.000 \\
\hline France & -0.201 & 0.019 & 0.000 \\
\hline Germany & -0.080 & 0.018 & 0.000 \\
\hline Poland & -0.229 & 0.018 & 0.000 \\
\hline Hungary & -0.089 & 0.021 & 0.000 \\
\hline Gender (base: female) & 0.018 & 0.012 & 0.132 \\
\hline Child (base: no) & -0.002 & 0.011 & 0.837 \\
\hline Age & -0.003 & 0.000 & 0.000 \\
\hline BMI & 0.000 & 0.001 & 0.426 \\
\hline \multicolumn{4}{|l|}{ SOC (base: managerial, professional) } \\
\hline Intermediate, small emp. & -0.021 & 0.014 & 0.116 \\
\hline Lower supervisory and technical & -0.100 & 0.017 & 0.000 \\
\hline Semi-routine and routine & -0.117 & 0.015 & 0.000 \\
\hline$R^{2}$ & .065 & & \\
\hline \multicolumn{4}{|l|}{ Dependent: Interest in healthy eating } \\
\hline Intercept & 2.614 & 0.710 & 0.000 \\
\hline \multicolumn{4}{|l|}{ Country (base: UK) } \\
\hline Sweden & 0.366 & 0.035 & 0.000 \\
\hline France & 0.017 & 0.038 & 0.663 \\
\hline Germany & 0.374 & 0.038 & 0.000 \\
\hline Poland & 0.274 & 0.036 & 0.000 \\
\hline Hungary & 0.219 & 0.041 & 0.000 \\
\hline Gender (base: female) & 0.230 & 0.023 & 0.000 \\
\hline Age & -0.009 & 0.001 & 0.000 \\
\hline BMI & 0.008 & 0.002 & 0.000 \\
\hline Child (base: no) & 0.039 & 0.022 & 0.080 \\
\hline \multicolumn{4}{|l|}{ SOC (base: managerial, professional) } \\
\hline Intermediate, small emp. & 0.057 & 0.027 & 0.032 \\
\hline Lower supervisory and technical & 0.126 & 0.033 & 0.000 \\
\hline Semi-routine and routine & 0.152 & 0.030 & 0.000 \\
\hline$R^{2}$ & .111 & & \\
\hline
\end{tabular}

on the probability of using nutrition information in the shop $(p<.01$ in all cases except for social grade 2 vs social grade 1 in its effects via interest in healthy eating, where $p<.04$ ). Note also that the gender effect becomes insignificant in the third step, when the situational factors are introduced. This may be related to the fact that women were more likely to have health/nutrition as their main reason for choice compared to men $\left(\chi^{2}=71.5, d f=3, p=.000\right)$.

\section{Understanding of FOP nutrition labels}

Mean subjective understanding of GDA labels, measured on a 10-point scale (don't understand at all - understand extremely well) was 7.1 in Poland and in the UK, 6.7 in Sweden and France, 6.3 in Hungary and 5.3 in Germany.

\section{Conceptual understanding}

Table 7 shows the distribution of answers to the three multiple-choice questions measuring conceptual understanding of GDA labels. Respondents in the UK, Sweden and Germany were generally most likely to come up with the right answers. The share of respondents ticking the right answer (out of four) concerning the definition of GDA was above $50 \%$ in these three countries and noticeably lower in the other three. France was the only country where the most frequently ticked answer actually was a wrong one. The share of respondents ticking the right answer (out of three) on the interpretation of a GDA reference value of $70 \mathrm{~g}$ for fat ranged from $88.6 \%$ in the UK down to $42.0 \%$ in France. The share of correct answers was lowest for the question on whether GDA information is per serving or per $100 \mathrm{~g}$, although the correct answer was the one most frequently selected in the UK, Sweden, France and Germany, but not in Poland and Hungary.

As noted above, two additional measures were obtained for checking conceptual understanding. Respondents were shown the label of a real product with a GDA label containing the information that the fat content of this product was $12 \%$ of the GDA for fat (Swedish example). Of five possible answers (the GDA of fat is $12 \mathrm{~g} /$ around 12 servings of this product would contain my total guideline daily amount of fat/the product contains $12 \mathrm{~g}$ of fat $/ 12 \%$ of the product is fat/it contains $12 \%$ of my GDA of fat), the share of correct answers among questionnaires returned was $65.4 \%$ in Germany, $55.8 \%$ in France, $49.9 \%$ in Hungary, 48.9\% in Sweden and 33.3\% in Poland (In the UK study, the correct answer referred to the fat content in absolute grams, not to the GDA percentage, thus not providing a test of GDA understanding; this was changed in the other country studies as shown above. The UK result is therefore not reported here). Respondents also had to answer whether their total intake of sugar would be more, equal to or less than the GDA for sugar if they ate on the same day one 
Table 7 Conceptual understanding of GDA labels (answers in \% of questionnaires returned, correct answers in bold)

\begin{tabular}{|c|c|c|c|c|c|c|c|c|}
\hline & & UK & Sweden & France & Germany & Poland & Hungary & Total \\
\hline \multirow{5}{*}{$\begin{array}{l}\text { In your opinion, which of } \\
\text { the following best describes } \\
\text { what GDA means? }\end{array}$} & $\begin{array}{l}\text { Guide to the amount of different foods } \\
\text { a person should be eating in a day }\end{array}$ & 12.9 & 4.1 & 21.1 & 9.2 & 21.4 & 19.6 & 14.7 \\
\hline & $\begin{array}{l}\text { Guide to the minimum amount of } \\
\text { energy (calories) and some nutrients } \\
\text { (e.g. fat, saturated fat/saturates, salt, } \\
\text { sugars) a person should be eating } \\
\text { in a day }\end{array}$ & 13.5 & 16.8 & 14.2 & 23.2 & 27.6 & 25.3 & 20.5 \\
\hline & $\begin{array}{l}\text { Exact amount of energy (calories) and } \\
\text { some nutrients (e.g. fat, saturated } \\
\text { fat/saturates, salt, sugars) a person } \\
\text { should be eating every day }\end{array}$ & 10.5 & 12.1 & 33.4 & 15.3 & 21.0 & 19.1 & 18.3 \\
\hline & $\begin{array}{l}\text { Guide to the amount of energy } \\
\text { (calories) and maximum amount of } \\
\text { some nutrients (e.g. fat, saturated } \\
\text { fat/saturates, salt, sugars) a person } \\
\text { should be eating in a day }\end{array}$ & 61.0 & 65.3 & 26.8 & 50.3 & 29.5 & 35.7 & 44.8 \\
\hline & Not answered & 2.1 & 1.7 & 4.6 & 2.0 & 0.5 & 0.3 & 1.7 \\
\hline \multirow{5}{*}{$\begin{array}{l}\text { Complete the sentence: } \\
\text { GDA indicates, as a } \\
\text { percentage of an adult's } \\
\text { daily needs, the levels of } \\
\text { nutrients }\end{array}$} & In $100 \mathrm{~g}$ of the food & 18.6 & 28.1 & 13.8 & 27.1 & 40.6 & 40.3 & 29.1 \\
\hline & In a serving of the food & 47.3 & 35.9 & 55.8 & 49.4 & 27.0 & 31.9 & 39.6 \\
\hline & Both of the above answers are correct & 19.0 & 16.4 & 17.6 & 17.1 & 19.8 & 12.7 & 17.5 \\
\hline & None of these answers is correct & 12.4 & 16.3 & 9.1 & 4.7 & 12.4 & 14.7 & 11.9 \\
\hline & Not answered & 2.7 & 3.2 & 3.6 & 1.7 & 0.1 & 0.6 & 1.9 \\
\hline \multirow{4}{*}{$\begin{array}{l}\text { If a food label says the } \\
\text { average adult GDA for fat } \\
\text { is } 70 \mathrm{~g} \text {, what do you think } \\
\text { this means? }\end{array}$} & $\begin{array}{l}\text { An average adult should eat at least } \\
70 \mathrm{~g} \text { fat a day }\end{array}$ & 7.1 & 16.7 & 32.5 & 10.3 & 26.6 & 25.0 & 20.0 \\
\hline & $\begin{array}{l}\text { An average adult should eat exactly } \\
70 \mathrm{~g} \text { fat a day }\end{array}$ & 2.1 & 11.1 & 21.2 & 6.3 & 22.8 & 10.1 & 13.3 \\
\hline & $\begin{array}{l}\text { An average adult should eat no more } \\
\text { than } 70 \mathrm{~g} \text { fat a day }\end{array}$ & 88.6 & 71.4 & 42.0 & 82.3 & 50.5 & 64.3 & 65.4 \\
\hline & Not answered & 2.3 & 0.8 & 4.2 & 1.1 & 0.1 & 0.6 & 1.3 \\
\hline
\end{tabular}

serving of each of three (real) products that were presented to them with GDA labels; here the percentage of correct answers among questionnaires returned was 74.2 in the UK, 58.3 in Germany, 51.5 in Sweden, 50.6 in Hungary, 43.0 in France and 39.6 in Poland.

In order to investigate determinants of conceptual understanding of GDAs, a score was computed giving the number of correct answers to the three questions in Table 7 (i.e. the range of the score is 0 to 3). Demographic and psychographic determinants were sought linked to this score in a regression analysis conducted in two blocks, paralleling the analysis conducted on determinants of use of nutrition information in the store (see Table 8). Country has the effect already seen in Table 7, with the UK, Germany and Sweden having higher numbers of correct answers. Number of correct answers also decreases with age and with social grade. More interest in healthy eating and a higher degree of nutrition knowledge increase the number of correct answers. Again the effects of the demographic variables become weaker when the second block is added, suggesting that some effects of the demographic variables might be mediated by interest in healthy eating and nutrition knowledge. Combining the results in Tables 6 and 8 and computing the Sobel test statistic for indirect effects of the demographic variables on conceptual understanding of GDAs supports that the effects of country, age and social grade on conceptual understanding of GDAs are partly mediated by interest in healthy eating and nutrition knowledge.

\section{Health inferences based on labels without context}

Respondents were asked to compare two products in terms of overall healthiness when the GDA label was the only information available. One product clearly dominated the other in terms of overall healthiness, as it was higher in calories, fat and saturated fat, while being identical in terms of sugar and salt. As Fig. 2 shows, by far most respondents in all countries could correctly identify the healthier of the two products.

Respondents also had to identify the healthiest and the least healthy of three products, again with only the GDA label information available. Here, the ranking of the products depended on the weight assigned to calories and the four nutrients in the health evaluation. As can be seen in Fig. 3a, respondents largely agreed that the product that was higher in calories, fat and salt was the least healthy, and most of them thought that of the two products that were 
Table 8 Determinants of conceptual understanding of GDA label (regression)

\begin{tabular}{|c|c|c|c|}
\hline & $\mathrm{B}$ & SE & Sig. \\
\hline \multicolumn{4}{|l|}{ Step 1: demographics only } \\
\hline Intercept & 1.326 & 0.088 & 0.000 \\
\hline \multicolumn{4}{|l|}{ Country (base: UK) } \\
\hline Sweden & -0.317 & 0.044 & 0.000 \\
\hline France & -0.754 & 0.047 & 0.000 \\
\hline Germany & -0.208 & 0.048 & 0.000 \\
\hline Poland & -0.976 & 0.045 & 0.000 \\
\hline Hungary & -0.728 & 0.051 & 0.000 \\
\hline Gender (base: female) & -0.017 & 0.029 & 0.563 \\
\hline Child (base: no) & 0.026 & 0.028 & 0.344 \\
\hline Age & -0.004 & 0.001 & 0.000 \\
\hline BMI & 0.003 & 0.003 & 0,229 \\
\hline \multicolumn{4}{|c|}{ Social grade (base: managerial, professional) } \\
\hline Intermediate, small emp. & -0.092 & 0.033 & 0.006 \\
\hline Lower supervisory and technical & -0.197 & 0.041 & 0.000 \\
\hline Semi-routine and routine & -0.139 & 0.037 & 0.000 \\
\hline$R^{2}$ & .139 & & \\
\hline \multicolumn{4}{|c|}{ Step 2: demographics + nutrition knowledge, interest in healthy eating } \\
\hline Intercept & 0.917 & 0.120 & 0.000 \\
\hline \multicolumn{4}{|l|}{ Country (base: UK) } \\
\hline Sweden & -0.244 & 0.045 & 0.000 \\
\hline France & -0.692 & 0.048 & 0.000 \\
\hline Germany & -0.169 & 0.049 & 0.001 \\
\hline Poland & -0.889 & 0.046 & 0.000 \\
\hline Hungary & -0.695 & 0.052 & 0.000 \\
\hline Gender (base: female) & -0.008 & 0.030 & 0.785 \\
\hline Child (base: no) & 0.037 & 0.028 & 0.186 \\
\hline Age & -0.003 & 0.001 & 0.000 \\
\hline BMI & 0.004 & 0.003 & 0.147 \\
\hline \multicolumn{4}{|c|}{ Social grade (base: managerial, professional) } \\
\hline Intermediate, small emp. & -0.087 & 0.033 & 0.009 \\
\hline Lower supervisory and technical & -0.148 & 0.042 & 0.000 \\
\hline Semi-routine and routine & -0.067 & 0.038 & 0.076 \\
\hline Interest in health eating & -0.073 & 0.019 & 0.000 \\
\hline Nutrition knowledge & 0.373 & 0.037 & 0.000 \\
\hline$R^{2}$ & .165 & & \\
\hline
\end{tabular}

lower in calories and fat the one that was lower in saturated fat was the healthiest. In Fig. 3b, again the product higher in calories and fat was the one most respondents ranked as the least healthy, but in terms of which product was healthiest the rankings are more distributed, as one of the two other products was higher in salt and the other higher in saturates, and it seems that respondents differed in the weighting given to these two nutrients. One should note that in the French sample the French Repères Nutritionnels Journaliers label was used which does not include information on saturates. This probably explains the high proportion of French respondents ranking product $G$ (the one which was high in saturates) as the most healthy.

\section{Substantial understanding and health inferences} when choosing between three ready meals

In each national subsample, substantial understanding and health inferences were measured with regard to a set of three ready meals. The three ready meals were selected from the products on the market in the respective country, and from the assortment of the retailers participating in the study. Hence, the stimulus material differed between countries. Table 9 gives a characterization of the products in the various sets. Respondents received scanned images of the whole packages, both front and back. All sets except the Swedish set had GDA information on the front of the 
package; for Sweden, one of the products had a keyhole logo on the front. All products had nutrition grids (tables or lists) on the back.

The questions asked to respondents with regard to the set of three products were the same in all countries. Respondents first had to rank the three products in terms of overall healthiness and then had to answer five questions on nutrient content (see Table 10). The share of correct answers to those questions requiring a relative comparison of nutrient content between the three products is generally high. Shares of correct answers are lower for the question "Which of these three products provides you with more than half of your guideline daily amount of fat". This question required not only a comparison between the products, but also a comparison with the GDA for fat. It was most difficult for the Swedish set, as it contained no GDA information and respondents would need to know the GDA for fat from other sources. But also in Poland and Hungary, where the GDA percentage was on the front of the pack, the share of correct answers is only slightly above the chance level.
Table 11 gives the results from the ranking, also indicating the correct rankings from a nutritional perspective. In the UK, France and Germany, by far most of the respondents came up with the correct ranking. Figures are lower in Poland, Hungary and Sweden. The Swedish result is interesting in that finding the healthiest alternative could have been accomplished by just looking for the keyhole; still, the product carrying the keyhole was ranked first only by $56.9 \%$ of the Swedish returned questionnaires. Since the keyhole has very high awareness in Sweden (over 95\% as measured in this study), the result seems to suggest that people looked for additional information beyond the keyhole.

A coding of the results from the open question asking which information respondents had used to arrive at the ranking showed again fat and calories to be the most widely used pieces of information (both $47 \%$ of respondents) followed by ingredients, sodium/salt and sugar. This finding must be related to the choice of product category for this task - ready meals which tend to be higher in fat rather than sugar.

Table 9 Stimulus material ready meal task

\begin{tabular}{|c|c|c|c|c|c|}
\hline & Product & Nutrition information & Product A & Product B & Product C \\
\hline UK & $\begin{array}{l}\text { Chilled } \\
\text { pasta } \\
\text { ready } \\
\text { meal }\end{array}$ & $\begin{array}{l}\text { GDA (per pack) on front, nutrition table per } \\
\text { pack and per } 100 \mathrm{~g} \text { on back, product B has } \\
\text { also \% GDA and absolute GDA on back }\end{array}$ & $\begin{array}{l}\text { Calories } 559 / 28 \% \text {, } \\
\text { sugar } 2 \mathrm{~g} / 2 \% \text {, } \\
\text { fat } 29.6 \mathrm{~g} / 42 \% \text {, } \\
\text { saturates } 15.6 \mathrm{~g} / 78 \% \text {, } \\
\text { salt } 2.4 \mathrm{~g} / 39 \%\end{array}$ & $\begin{array}{l}\text { Calories } 400 / 20 \% \text {, } \\
\text { sugar } 4.4 \mathrm{~g} / 5 \% \text {, fat } \\
8.8 \mathrm{~g} / 13 \% \text {, saturates } \\
4.8 \mathrm{~g} / 24 \% \text {, salt } 1.8 \mathrm{~g} / \\
30 \% \text {, carries mark } \\
\text { with Weight } \\
\text { Watchers points, is } \\
\text { part of 'light choices' } \\
\text { product range }\end{array}$ & $\begin{array}{l}\text { Calories } 615 / 31 \% \text {, sugar } \\
12.2 \mathrm{~g} / 14 \% \text {, fat } 40.1 \mathrm{~g} / \\
57 \% \text {, saturates } 16.4 \mathrm{~g} / \\
82 \% \text {, salt } 2 \mathrm{~g} / 33 \%\end{array}$ \\
\hline Sweden & $\begin{array}{l}\text { Frozen } \\
\text { ready } \\
\text { meal }\end{array}$ & $\begin{array}{l}\text { Nutrition table per pack and per } 100 \mathrm{~g} \text { on } \\
\text { back; one product carries keyhole }\end{array}$ & $\begin{array}{l}\text { Calories } 380 \text {, sugar } \\
9.1 \mathrm{~g} \text {, fat } 14 \mathrm{~g} \text {, } \\
\text { saturates } 5.8 \mathrm{~g} \text {, salt } \\
4.2 \mathrm{~g} \text {, has on back } \\
\text { claim 'rich in fibre' }\end{array}$ & $\begin{array}{l}\text { Calories } 380 \text {, sugar } 11 \\
\mathrm{~g} \text {, fat } 15 \mathrm{~g} \text {, saturates } \\
6.4 \mathrm{~g} \text {, salt } 3.7 \mathrm{~g}\end{array}$ & $\begin{array}{l}\text { Calories } 430 \text {, sugar } \\
6.1 \mathrm{~g} \text {, fat } 12 \mathrm{~g}, \\
\text { saturates } 1.1 \mathrm{~g}, \\
\text { salt } 3.5 \mathrm{~g} \text {, carries } \\
\text { keyhole logo }\end{array}$ \\
\hline France & $\begin{array}{l}\text { Chilled } \\
\text { ready } \\
\text { meal }\end{array}$ & $\begin{array}{l}\text { GDA (per pack) without saturates on front, } \\
\text { nutrition table per pack and per } 100 \mathrm{~g} \text { on } \\
\text { back }\end{array}$ & $\begin{array}{l}\text { Calories } 542 / 27 \% \text {, } \\
\text { sugar } 10.1 \mathrm{~g} / 20 \% \text {, } \\
\text { fat } 24.6 \mathrm{~g} / 34 \% \text {, } \\
\text { saturates } 13.8 \mathrm{~g}, \\
\text { salt } 4.3 \mathrm{~g} / 72 \%\end{array}$ & $\begin{array}{l}\text { Calories } 499 / 25 \%, \\
\text { sugar } 7 \mathrm{~g} / 8 \%, \\
\text { fat } 21.2 \mathrm{~g} / 29 \% \text {, } \\
\text { saturates } 7.2 \mathrm{~g}, \\
\text { salt } 3.5 \mathrm{~g} / 58 \%\end{array}$ & $\begin{array}{l}\text { Calories } 266 \text {, sugar } 9 \mathrm{~g} / \\
10 \% \text {, fat } 14.7 \mathrm{~g} / 21 \% \text {, } \\
\text { saturates } 6 \mathrm{~g} \text {, salt } \\
2.1 \mathrm{~g} / 36 \%\end{array}$ \\
\hline Germany & $\begin{array}{c}\text { Frozen } \\
\text { pizza }\end{array}$ & $\begin{array}{l}\text { GDA (per half pizza) on front, nutrition table } \\
\text { per half pizza and per } 100 \mathrm{~g} \text {, GDAs and } \\
\text { absolute GDA values on back }\end{array}$ & $\begin{array}{l}\text { Calories } 405 / 20 \% \text {, } \\
\text { sugar } 6.5 \mathrm{~g} / 7 \% \text {, fat } 17 \\
\text { g/24\%, saturates } 7.5 \\
\mathrm{~g} / 38 \%, \text { salt } \\
2.6 \mathrm{~g} / 43 \%\end{array}$ & $\begin{array}{l}\text { Calories } 318 / 16 \%, \\
\text { sugar } 6.7 \mathrm{~g} / 7 \%, \\
\text { fat } 9.6 \mathrm{~g} / 14 \%, \\
\text { saturates } 4.4 \mathrm{~g} / 2 \% \text {, } \\
\text { salt } 2.2 \mathrm{~g} / 37 \%\end{array}$ & $\begin{array}{l}\text { Calories } 422 / 21 \% \text {, sugar } \\
6 \mathrm{~g} / 7 \% \text {, fat } \\
18 \mathrm{~g} / 26 \% \text {, saturates } 10 \\
\mathrm{~g} / 50 \% \text {, salt } 2.6 \mathrm{~g} / 43 \%\end{array}$ \\
\hline Poland & $\begin{array}{c}\text { Frozen } \\
\text { pizza }\end{array}$ & $\begin{array}{l}\text { GDA (per half pizza) on front, nutrition list } \\
\text { per } 100 \mathrm{~g} \text { on back }\end{array}$ & $\begin{array}{l}\text { Calories } 310 / 16 \% \text {, } \\
\text { sugar } 0.8 \mathrm{~g} / 1 \% \text {, } \\
\text { fat } 10.5 \mathrm{~g} / 15 \% \text {, } \\
\text { saturates } 3 \mathrm{~g} / 15 \% \text {, salt } \\
1.7 \mathrm{~g} / 28 \%\end{array}$ & $\begin{array}{l}\text { Calories } 295 / 15 \%, \\
\text { sugar } 0.7 \mathrm{~g} / 1 \%, \\
\text { fat } 9.5 \mathrm{~g} / 14 \%, \\
\text { saturates } 2.3 \mathrm{~g} / 12 \%, \\
\text { salt } 1.6 \mathrm{~g} / 27 \%\end{array}$ & $\begin{array}{l}\text { Calories } 355 / 18 \% \text {, sugar } \\
0.8 / 1 \% \text {, fat } \\
15 \mathrm{~g} / 21 \% \text {, saturates } 4.5 \\
\mathrm{~g} / 23 \% \text {, salt } 2 \mathrm{~g} / 33 \%\end{array}$ \\
\hline Hungary & $\begin{array}{c}\text { Frozen } \\
\text { pizza }\end{array}$ & $\begin{array}{l}\text { GDA (per half pizza) on front, nutrition list per } \\
100 \mathrm{~g} \text { on back }\end{array}$ & $\begin{array}{l}\text { Calories } 295 / 15 \% \text {, } \\
\text { sugar } 0.7 \mathrm{~g} / 1 \% \text {, fat } \\
9.5 \mathrm{~g} / 14 \% \text {, saturates } \\
2.3 \mathrm{~g} / 12 \% \text {, salt } 1.6 \mathrm{~g} / \\
27 \%\end{array}$ & $\begin{array}{l}\text { Calories } 310 / 16 \%, \\
\text { sugar } 0.8 \mathrm{~g} / 1 \%, \\
\text { fat } 10.5 \mathrm{~g} / 15 \%, \\
\text { saturates } 3 \mathrm{~g} / 15 \%, \\
\text { salt } 1.7 \mathrm{~g} / 28 \%\end{array}$ & $\begin{array}{l}\text { Calories } 355 / 18 \% \text {, sugar } \\
0.8 / 1 \% \text {, fat } \\
15 \mathrm{~g} / 21 \% \text {, saturates } 4.5 \\
\mathrm{~g} / 23 \% \text {, salt } 2 \mathrm{~g} / 33 \%\end{array}$ \\
\hline
\end{tabular}


Table 10 Evaluation of ready meals with regard to calories and four nutrients in response to question "Which of these three products would you say...?" (correct answers in \% of questionnaires returned)

\begin{tabular}{|c|c|c|c|c|c|c|}
\hline & UK & Sweden & France & Germany & Poland & Hungary \\
\hline Is lowest in saturated fat per serving & 88.5 & 80.2 & 78.6 & 87.0 & 51.5 & 71.3 \\
\hline Has the lowest calories per $100 \mathrm{~g}$ & 89.1 & 53.7 & 87.0 & 92.8 & 59.6 & 72.7 \\
\hline Contains the highest percentage of GDA for sugar & 75.8 & 68.8 & 66.6 & 65.2 & 60.6 & 61.6 \\
\hline Provides you with more than half of your GDA of fat & 78.7 & 11.7 & 62.4 & 57.4 & 38.1 & 34.7 \\
\hline Contains the most salt & 83.0 & 72.9 & 80.2 & 71.0 & 76.9 & 86.2 \\
\hline
\end{tabular}

An index was computed counting the number of correct answers for both the substantial understanding and the health inference tasks (range: 0-8). The effect of demographic and psychographic variables on this index was estimated by regression analysis (see Table 12). Note that the country effect here will be the combined effect of country-specific differences and of differences in the stimulus sets used in the six countries.

We can see the country/stimulus set differences already discussed, resulting in the highest number of correct answers for the UK, France and Germany and lower values for Sweden, Poland and Hungary. The number of correct answers decreases with age and with social grade; it increases with interest in healthy eating and nutrition knowledge. Effects of age and social grade again appear to be partly mediated by the two psychographic variables. Mediation analysis cannot be carried out with regard to country here, as the country variable here also included differences in stimulus sets.

\section{Discussion and conclusions}

Our first aim in this study was to get a realistic estimate of the degree of usage of nutrition label information by combining observation in the store with an in-store interview concerning the observed purchase. Of all shoppers observed, $16.8 \%$ did look for nutrition information, and there was a good deal of variation both with regard to countries and product categories. We should also note that this figure represents rather the result of a sample of product choices than a sample of shoppers - a shopper who was not observed looking for nutrition information in this study could conceivably do so when shopping for a different product category, and vice versa. Also, the differences found between the six product categories indicate that the overall figures would look different if a different set of products had been used.

Whether an average of $16.8 \%$ of shoppers that said they had looked for nutrition information on the label is high or
Table 11 Health inferences for three ready meals (answers in $\%$ of questionnaires returned, correct answers in bold)

\begin{tabular}{|c|c|c|c|c|c|}
\hline & Product & Healthiest & Second healthiest & Third healthiest & Not answered \\
\hline \multirow[t]{3}{*}{ UK } & $\mathrm{A}$ & 4.2 & 83.7 & 7.1 & 5.1 \\
\hline & $\mathrm{B}$ & 87.5 & 5.9 & 2.4 & 4.2 \\
\hline & $\mathrm{C}$ & 3.7 & 5.9 & 85.4 & 5.0 \\
\hline \multirow[t]{3}{*}{ Sweden } & $\mathrm{A}$ & 32.1 & 51.5 & 11.7 & 4.7 \\
\hline & $\mathrm{B}$ & 6.4 & 16.7 & 72.0 & 4.8 \\
\hline & $\mathrm{C}$ & 56.9 & 27.0 & 12.2 & 3.9 \\
\hline \multirow[t]{3}{*}{ France } & A & 7.2 & 15.2 & 72.0 & 5.5 \\
\hline & $\mathrm{B}$ & 4.3 & 73.5 & 17.0 & 5.2 \\
\hline & $\mathrm{C}$ & 83.6 & 6.8 & 5.4 & 4.2 \\
\hline \multirow[t]{3}{*}{ Germany } & $\mathrm{A}$ & 1.6 & 55.2 & 36.9 & 6.3 \\
\hline & $\mathrm{B}$ & 93.9 & 2.7 & 1.6 & 1.8 \\
\hline & $\mathrm{C}$ & 3.7 & 35.3 & 54.7 & 6.3 \\
\hline \multirow[t]{3}{*}{ Poland } & $\mathrm{A}$ & 43.5 & 42.9 & 13.6 & 0 \\
\hline & $\mathrm{B}$ & 48.9 & 40.8 & 10.3 & 0 \\
\hline & $\mathrm{C}$ & 7.6 & 16.3 & 76.1 & 0 \\
\hline \multirow[t]{3}{*}{ Hungary } & $\mathrm{A}$ & 49.6 & 42.2 & 6.1 & 2.0 \\
\hline & $\mathrm{B}$ & 44.5 & 49.4 & 4.0 & 2.1 \\
\hline & $\mathrm{C}$ & 4.1 & 6.0 & 87.5 & 2.4 \\
\hline
\end{tabular}


Table 12 Determinants of understanding of nutrition information on ready meal packages (regression)

\begin{tabular}{|c|c|c|c|}
\hline & $\mathrm{B}$ & SE & Sig. \\
\hline \multicolumn{4}{|l|}{ Step 1: demographics only } \\
\hline Intercept & 5.671 & 0.202 & 0.000 \\
\hline \multicolumn{4}{|l|}{ Country (base: UK) } \\
\hline Sweden & -2.092 & 0.110 & 0.000 \\
\hline France & -0.693 & 0.118 & 0.000 \\
\hline Germany & -0.984 & 0.119 & 0.000 \\
\hline Poland & -2.385 & 0.112 & 0.000 \\
\hline Hungary & -1.733 & 0.126 & 0.000 \\
\hline Gender (base: female) & -0.072 & 0.067 & 0.280 \\
\hline Child (base: no) & -0.025 & 0.063 & 0.694 \\
\hline Age & -0.016 & 0.002 & 0.000 \\
\hline BMI & -0.002 & 0.007 & 0.755 \\
\hline \multicolumn{4}{|c|}{ Social grade (base: managerial, professional) } \\
\hline Intermediate, small emp. & -0.034 & 0.076 & 0.654 \\
\hline Lower supervisory and technical & -0.207 & 0.095 & 0.028 \\
\hline Semi-routine and routine & -0.334 & 0.085 & 0.000 \\
\hline$R^{2}$ & .152 & & \\
\hline \multicolumn{4}{|c|}{ Step 2: demographics + nutrition knowledge, interest in healthy eating } \\
\hline Intercept & 3.698 & 0.269 & 0.000 \\
\hline \multicolumn{4}{|l|}{ Country (base: UK) } \\
\hline Sweden & -1.907 & 0.110 & 0.000 \\
\hline France & -0.400 & 0.117 & 0.001 \\
\hline Germany & -0.888 & 0.117 & 0.000 \\
\hline Poland & -2.098 & 0.112 & 0.000 \\
\hline Hungary & -1.614 & 0.124 & 0.000 \\
\hline Gender (base: female) & -0.090 & 0.066 & 0.72 \\
\hline Child (base: no) & -0.023 & 0.062 & 0.715 \\
\hline Age & -0.012 & 0.002 & 0.000 \\
\hline BMI & 0.001 & 0.007 & 0.886 \\
\hline \multicolumn{4}{|c|}{ Social grade (base: managerial, professional) } \\
\hline Intermediate, small emp. & -0.022 & 0.074 & 0.763 \\
\hline Lower supervisory and technical & -0.077 & 0.093 & 0.405 \\
\hline Semi-routine and routine & -0.143 & 0.084 & 0.088 \\
\hline Interest in healthy eating & -0.075 & 0.043 & 0.078 \\
\hline Nutrition knowledge & 1.317 & 0.083 & 0.000 \\
\hline$R^{2}$ & .211 & & \\
\hline
\end{tabular}

low is debatable. It is lower than the figures resulting from studies employing self-reported behaviour, i.e. asking respondents for their own estimate on how often they use nutrition information when shopping. The fact that the figure was highest in the UK suggests that the prominence of nutritional issues and especially of issues relating to nutrition labelling in the public debate plays a role, but the other country differences are not readily explained in the same way. Clearly, other national and cultural differences warrant more attention, e.g. national differences in interest in healthy eating and in nutrition knowledge do play a role, although these in turn ask for further explanation.
The other aim of this study was to measure understanding of FOP nutrition information, especially the GDA label. Understanding of the concept of GDAs is good in the UK, Sweden and Germany, more limited in Hungary and Poland and questionable in France. However, when it comes to applying the label information for relative judgements of products, no matter whether with regard to single nutrients or with regard to overall healthiness, most respondents were able to come up with the right answers. It seems that intra-category comparisons are not inherently difficult for most people, a finding that is in line with earlier research (see Grunert and Wills 2007) and also with a recent study commissioned by 
the Food Standards Agency (Malam et al. 2009). Still, we do see country differences also here, again with the UK showing best performance across all tasks, giving further support to the hypothesis that the length and intensity of public debate on issues of nutrition and labelling leaves traces in the population.

In addition to the country-specific differences, we found effects of age, social grade, interest in healthy eating and nutrition knowledge on both use and understanding of nutrition information. Interest in healthy eating and nutrition knowledge mediate the effects of country, age and social grade, but only partly, and it may be a safe assumption that the remaining effect of social grade has to do with aspects of ability to process the information. Age has two opposite effects-older respondents tended to have more interest in healthy eating, but less nutrition knowledge.

With regard to the potential of increasing healthy consumer food choices by nutrition labelling, three overarching conclusions emerge. First, when it comes to making intra-category comparisons among products, the proportion of people who seem to be able to do that, if they are given easy-to-process information on calories and key nutrients, is considerably higher than the proportion of people actually doing this when they go shopping. This suggests that, at least with regard to such intra-category comparisons, the real hurdle does not seem to be people's ability to make use of the information, but rather people's motivation to do so. Second, the finding that the UK subsample consistently had higher scores on both use and understanding than the other subsamples suggests that an intensive public debate on nutrition and labelling issues can indeed affect people's thinking and behaviour. Third, it also became clear that considerable national differences remain, which cannot be solely explained in terms of differences in nutrition knowledge and differences in healthy eating and that attempts to promote healthy eating have to address these differences.

Two important limitations of the study should also be noted. First, even though shoppers may have looked at nutrition information in the store, this does not necessarily mean that this information has had an impact on their choice. Thus, the final question of whether nutrition labelling does increase the proportion of healthy choices in the store still remains unanswered. Second, this study has mainly investigated understanding of label information with regard to intra-category comparison. Using label information to compose meals, weekly shopping baskets and generally to manage one's dietary intake is a much more complex task, and little is known about the potential role of labelling therein.
Acknowledgement The authors would like to thank the participating retailers for granting permission to conduct the research in their stores, and especially those who agreed to provide the incentives for the consumers recruited in their stores.

Conflict of interest EUFIC receives funding from the European food and drink industry, and Klaus G. Grunert received funding from EUFIC to carry out this study.

Open Access This article is distributed under the terms of the Creative Commons Attribution Noncommercial License which permits any noncommercial use, distribution, and reproduction in any medium, provided the original author(s) and source are credited.

\section{References}

Baron RM, Kenny DA (1986) The moderator-mediator variable distinction in social psychological research: conceptual, strategic, and statistical considerations. J Pers Soc Psychol 51:11731182

Cadbury Schweppes (2005) Consumer exploration and understanding of potential pack labelling initiatives. Sundance, London

Cowburn G, Stockley L (2005) Consumer understanding and use of nutrition labelling: a systematic review. Public Health Nutr 8:21-28

Eagly AH, Chaiken S (1993) The psychology of attitudes. Harcourt Brace College, Fort Worth

Fernandez-Celemin L, Storcksdieck genannt Bonsmann S (2009) Current penetration of nutrition information on food labels in the EU $27 \&$ Turkey. FLABEL webinar. http://www.focusbiz.co.uk/ webinars/flabel/wp1/

Feunekes GIJ, Gortemaker IA, Willems AA, Lion R, van den Kommer M (2008) Front-of-pack nutrition labelling: testing effectiveness of different nutrition labelling formats front-ofpack in four European countries. Appetite 50:57-70

Food Standards Agency (2005) Quantitative evaluation of alternative food signposting concepts. Synovate, London

Food Standards Agency (2007) A balanced diet is a healthy diet: Eatwell Omnibus Survey. Food Standards Agency, London

Grunert KG, Wills JM (2007) A review of European research on consumer response to nutrition information on food labels. $\mathrm{J}$ Public Health 15:385-399

Grunert KG, Brunsø K, Bredahl L, Bech AC (2001) Food-related lifestyle: a segmentation approach to European food consumers. In: Frewer LJ, Risvik E, Schifferstein HNJ, von Alvensleben R (eds) Food, people and society: a European perspective of consumers' food choices. Springer, London, pp 211-230

Higginson C, Kirk TR, Rayner M, Draper S (2002) How do consumers use nutrition label information? Nutr Food Sci 32(4):145-152

Kardes FR, Posavac SS, Cronley ML (2004) Consumer inference: a review of processes, bases, and judgment contexts. J Consum Psychol 14(3):230-256

Kelly B, Hughes C, Chapman K, Louie JC, Dixon H, Crawford J, King L, Daube M, Slevin T (2009) Consumer testing of the acceptability and effectiveness of front-of-pack food labelling systems for the Australian grocery market. Health Promot Int 24 (2):120-129

Malam S, Clegg S, Kirwan S, McGinigal S, in association with Raats M, Barnett J, Senior V, Hodgkins C, Dean M (2009) Comprehension and use of UK nutrition signpost labelling schemes. British Market Research Bureau 
McGuire WJ (1985) Attitudes and attitude change. In: Lindzey G, Aronson E (eds) The handbook of social psychology, vol 2, 3rd edn. Random House, New York, pp 233-346

Parmenter K, Wardle J (1999) Development of a general nutrition knowledge questionnaire for adults. Eur J Clin Nutr 53(4):298-308

Peter JP, Olson JC, Grunert KG (1999) Consumer behaviour and marketing strategy. McGraw-Hill, Maidenhead
Roininen K, Lähteenmäki L, Tuorila H (1999) Quantification of consumer attitudes to health and hedonic characteristics of foods. Appetite 33:71-88

Solomon M, Bamossy G, Askegaard S, Hogg MK (2006) Consumer behaviour, a European perspective, 3rd edn. Prentice Hall, Harlow

Which (2006) Food labelling study. Conquest Research 